\title{
基礎疾患を有する超高齢者に緊急腹腔鏡下手術を施行した2例
}

トヨ夕記念病院 産婦人科 ${ }^{1}$ 、同 臨床検査科 病理 ${ }^{2}$ 古株哲也 ${ }^{1)}$ 、吉原雅人 ${ }^{1)}$ 、眞山学徳 ${ }^{1)}$ 、鵜飼真由 ${ }^{1)}$ 、小出菜月 ${ }^{1)}$ 、 近藤真哉 ${ }^{1)} 、$ 宮㟝のどか ${ }^{1)}$ 、原田統子 ${ }^{1)}$ 、北川 諭 ${ }^{2}$ 、西尾洋介 ${ }^{1)}$ 、 宇野 枢 ${ }^{1)}$ 、田野 翔 $^{11}$ 、岸上靖幸 ${ }^{1)}$ 、小口秀紀 ${ }^{1)}$

\section{Emergency Laparoscopic Surgery in Very Elderly Patients with Underlying Conditions: Two Case Reports}

\author{
Tetsuya Kokabu ${ }^{1)}$, Masato Yoshihara ${ }^{1)}$, Michinori Mayama ${ }^{1)}$, Mayu Ukai ${ }^{1)}$, Natsuki Koide ${ }^{1)}$, \\ Shinya Kondo ${ }^{1)}$, Nodoka Miyazaki ${ }^{1)}$, Toko Harata ${ }^{1)}$, Satoshi Kitagawa ${ }^{2)}$, Yosuke Nishio ${ }^{1)}$, \\ Kaname Uno $^{1)}$, Sho Tano ${ }^{1)}$, Yasuyuki Kishigami ${ }^{1)}$, Hidenori Oguchi ${ }^{1)}$ \\ Department of Obstetrics and Gynecology, Toyota Memorial Hospital ${ }^{1)}$, \\ Department of Pathology, Toyota Memorial Hospital ${ }^{2)}$
}

\begin{abstract}
As increasing surgical procedures for very elderly patients, especially over the age of 85 , are performed, maintaining the activity of daily living (ADL) postoperatively is becoming an important issue. We report two cases of very elderly patients who underwent emergency laparoscopic surgery and were discharged without any postoperative complications or ADL decline.

Case 1: A 92-year-old woman who was receiving anticoagulant therapy for chronic atrial fibrillation presented with a chief complaint of persistent abdominal pain. An abdominal MRI revealed a $27 \times 11 \mathrm{~cm}$ ovarian tumor. On the third day after admission, the patient developed acute respiratory failure because of compression of the diaphragm caused by a pleural effusion and the ovarian tumor; therefore, the patient underwent emergency laparoscopic surgery.

Case 2: An 89-year-old woman with a history of hypertension who was taking an antiplatelet agent presented at our hospital with a chief complaint of the sudden onset of lower abdominal pain. An abdominal CT scan demonstrated an intra-abdominal tumor and ascites. Rupture of an ovarian tumor was suspected and emergency laparoscopic surgery was performed.

In both cases, although perioperative intensive care was required, the patients were discharged with a status comparable to their preoperative ADL because of early rehabilitation. Due to the fact that a number of very elderly patients have underlying conditions, appropriate multidisciplinary management of perioperative and postoperative complications are required. If we can apply quality assurance to the performance of minimally invasive laparoscopic surgery, it will facilitate the maintenance of the ADL in very elderly patients.
\end{abstract}

Key words: activity of daily living, laparoscopic surgery, older adults

\section{【はじめに】}

わが国は世界屈指の長寿国であり、近年、高齢 社会から超高齢社会へと変遷しつつある。それに 伴い、85歳以上の超高齢者を手術する機会も増加 してきた。超高齢者における手術療法は、日常生
活動作（Activity of daily living: ADL）の低下を 防ぐことが最も重要な課題のひとつとなる。腹腔 鏡下手術は低侵襲であり、早期離床やADLの低 下を最小限に抑えることが期待できるため、超高 齢者の治療手段として有用と考えられる。しかし、 超高齢者では基礎疾患を有する場合が多いのに加 
えて、腹腔鏡下手術では従来法である開腹手術や 腟式手術では起こりえない合併症が生じる可能性 もある1)。このため婦人科領域では腹腔鏡下手術 が保険適応となって 20 年近く経過しょうとしてい るが2、基礎疾患を有することが多い超高齢者に 対する腹腔鏡下手術の報告は極めて少ない ${ }^{1)}$ 。今 回われわれは、基礎疾患を有する超高齢者に対し、 緊急腹腔鏡下手術を施行し、術後合併症やADL の低下をきたすことなく退院となった 2 例を経験 したので若干の文献的考察を加え報告する。

\section{【症 例 1】}

年齢：92歳

身長：149.5 cm、体重：53.6 kg

妊娠分娩歴：3 経妊 3 経産

月経歴：49歳閉経

既往歴：慢性心房細動、慢性心不全、高血圧、脂 質異常症

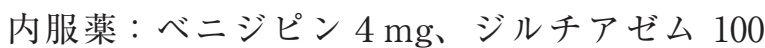
$\mathrm{mg} 、$ ベラパミル $40 \mathrm{mg}$ 、ワルファリン $1.5 \mathrm{mg}$ 、 ピタバスタチン $1 \mathrm{mg}$ 、フロセミド $30 \mathrm{mg}$ 家族歴：特記すべき事項なし
現病歴：ADLは自立していた。1 月月前から腹 部膨満感と呼吸困難感が増悪し、 1 週間前から下 腿浮腫が出現した。2 日前から持続する腹痛と食 事摂取困難を主訴に、当院救急外来に搬送となっ た。

来院時現症：来院時には軽度の呼吸苦を訴え、体 温は $37.1^{\circ} \mathrm{C}$ 、血圧は $115 / 59 \mathrm{mmHg}$ 、脈拍は 98 bpm、動脈血酸素飽和度 $\left(\mathrm{SpO}_{2}\right)$ は $2 \mathrm{~L} / \mathrm{min}$ の

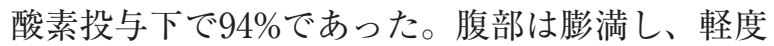
の圧痛を認めた。救急外来で施行した腹部単純 CTで腹腔内腫瘍を指摘され、精查治療目的に当 科紹介となった。内診所見では子宮は萎縮し、骨 盤から上腹部に達する超成人頭大の腫瘤を認め た。

検査所見：腹部単純CTを図 1 に示す。多房性で 一部に隔壁肥厚と壁在結節を有する襄胞性腫瘍を 認めた。経腹超音波断層法では、腫瘤は充実成分 を有する多房性囊胞性腫瘍であった（図 2 ）。入 院時の腹部MRIを図 3 に示す。T1強調像、T2強 調像で高信号を呈し、脂肪抑制像でも高信号の腹 腔内を占拠する $27.4 \times 10.9 \mathrm{~cm}$ 大の境界明瞭な楕 円形腫瘍を認めた。内部には充実成分と思われる

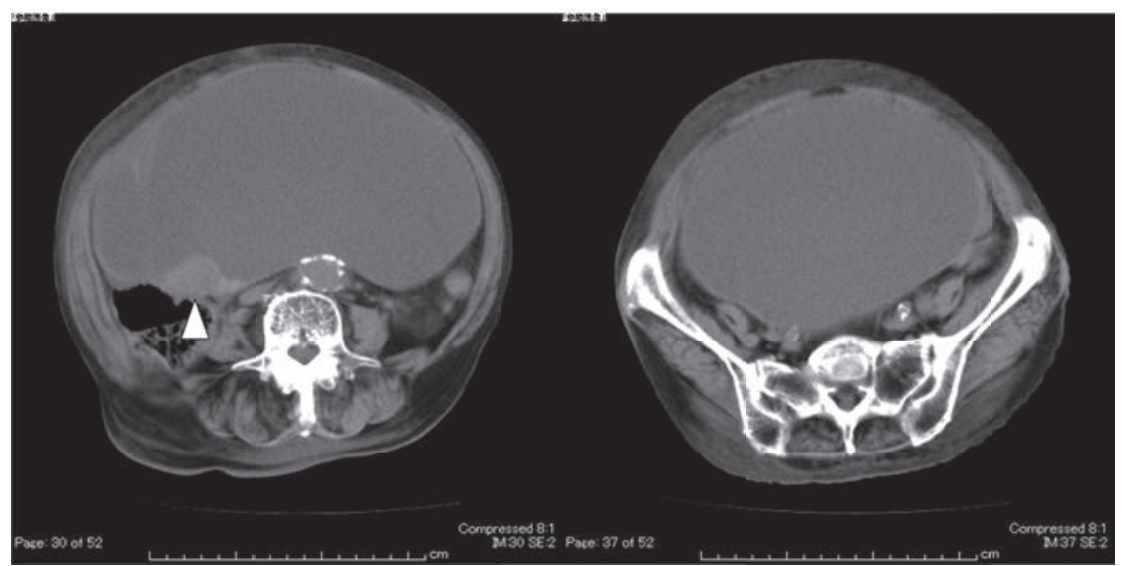

図 1 腹部単純CT

腫瘍は壁在結節 $(\Delta)$ を有し、骨盤腔から上腹部に達している

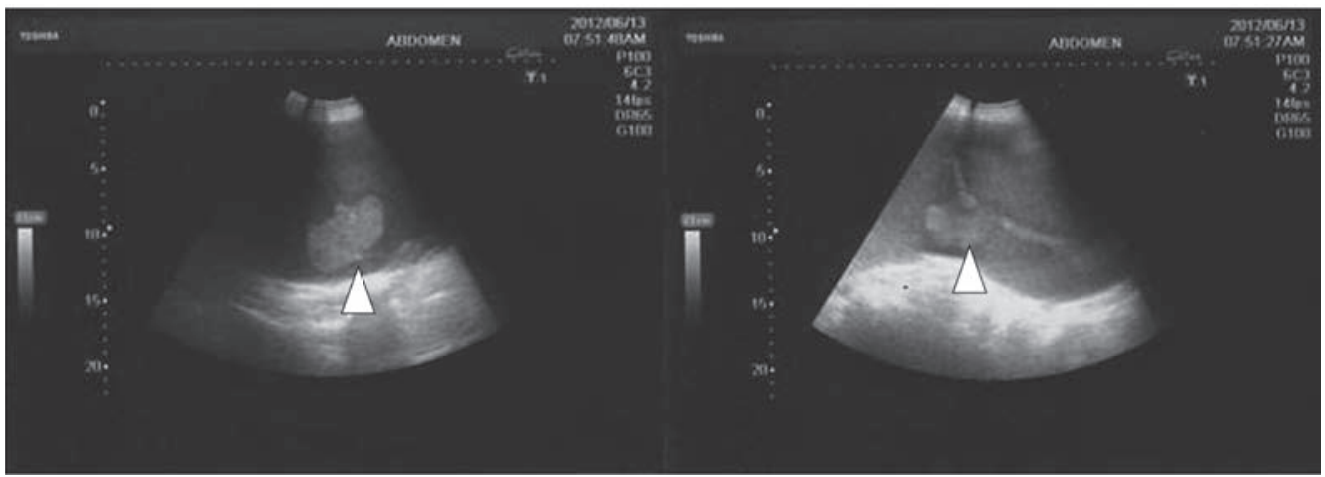

図2 経腹超音波断層法

腫瘍内に充実成分 $(\Delta)$ を認める 


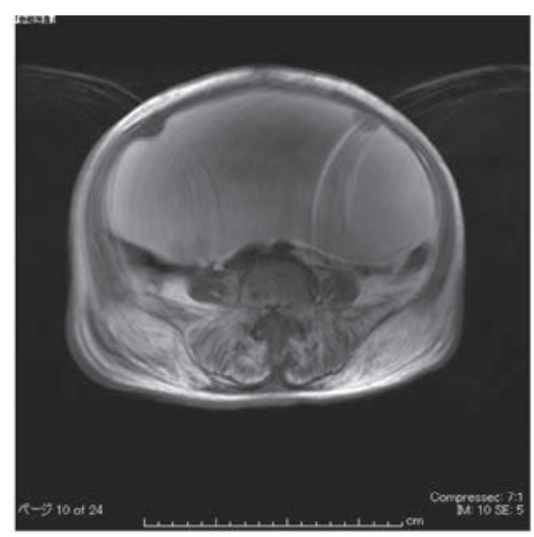

$\mathrm{T} 1$ 強調像

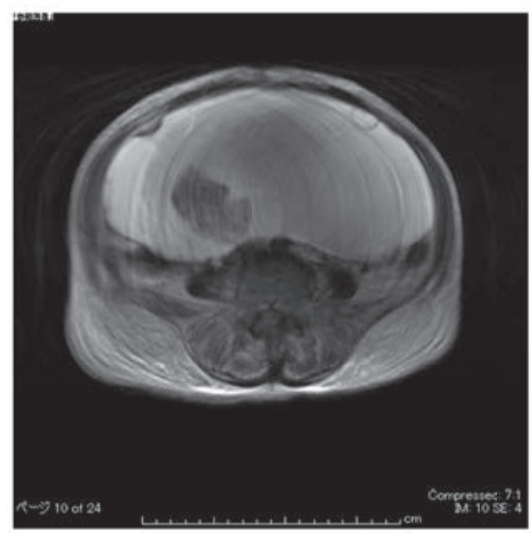

T2強調像

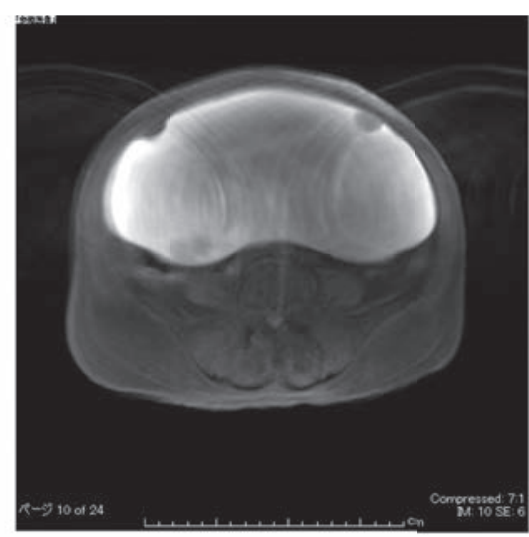

$T$ 1強調脂肪抑制像

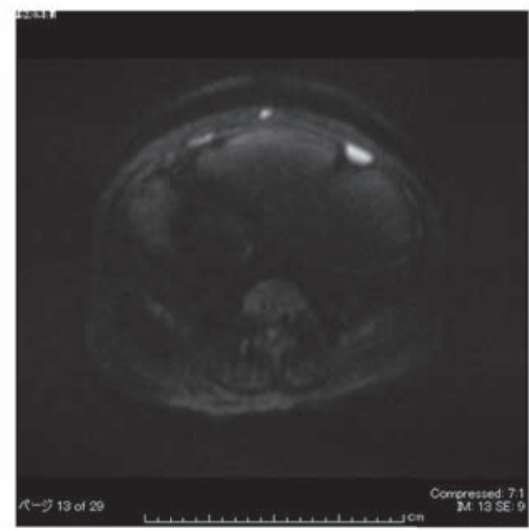

拡散強調像

図3 腹部MRI

腫瘍はT1強調、T2強調、脂肪抑制像で高信号を呈する内容物と、拡散強調像で高信号を呈 する壁在結節を認める

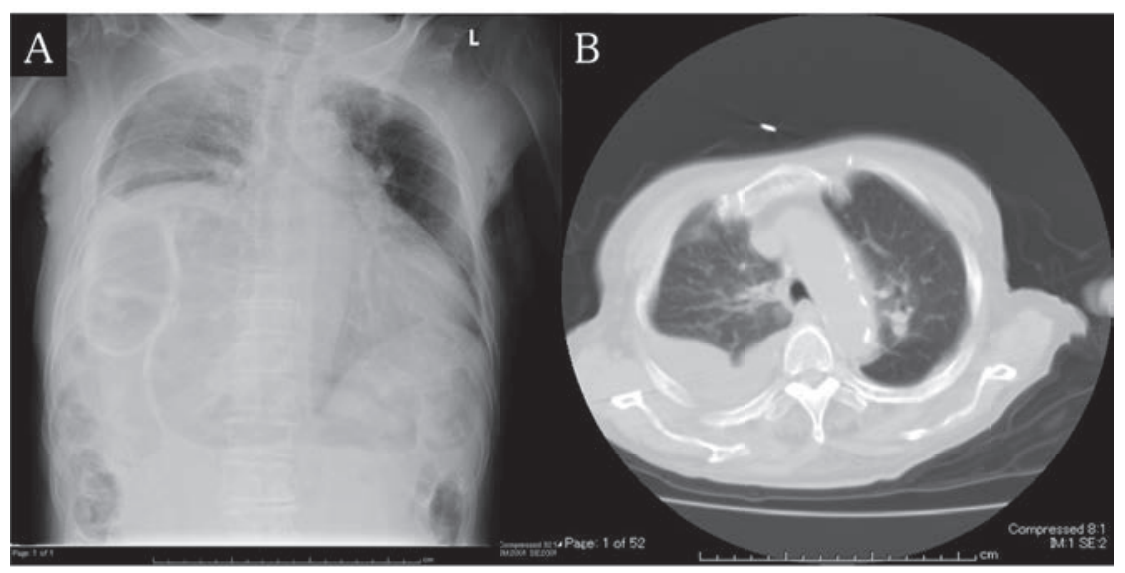

$A$ : 胸部単純 $X$ 線像

$B ：$ 胸部単純 CT

図 4 胸部単純X線像、CT

$\mathrm{A}:$ 肺の含気は低下し、横隔膜は著明に挙上している

$B ：$ 右胸水を認める

部位に拡散強調像で高信号を認めた。入院時の胸 部単純X線像（図 $4 \mathrm{~A}$ ) と胸部単純CT (図 $4 \mathrm{~B}$ ) を示す。右胸水と高度の横隔膜挙上を認め、両肺 の含気量は低下していた。初診時の血液検查所見 を表 1 に示す。WBCは10,100/ $\mu \mathrm{L} 、 \mathrm{CRP}$ は31.1 $\mathrm{mg} / \mathrm{dL}$ 著明な炎症反応を認めた。腫瘍マーカ
ーはCA125が108 U/mL、CA19-9が1,081 U/mL と高值を示していた。ワルファリン内服中であり、 PT INRが1.55とやや高值であった。

入院後経過：同日より入院管理とし、悪性卵巣腫 瘍の可能性も否定できないため、開腹手術を予定 した。入院 3 日目の早朝より呼吸苦を訴え、頻呼 
表 1 血液検査所見（症例 1 ）

\begin{tabular}{lclr}
\hline WBC & $10,100 / \mu \mathrm{L}$ & $\mathrm{TP}$ & $6.2 \mathrm{~g} / \mathrm{dL}$ \\
$\mathrm{RBC}$ & $355 \times 10^{4} / \mu \mathrm{L}$ & Alb & $3.4 \mathrm{~g} / \mathrm{dL}$ \\
$\mathrm{Hb}$ & $10.4 \mathrm{~g} / \mathrm{dL}$ & $\mathrm{BUN}$ & $21 \mathrm{mg} / \mathrm{dL}$ \\
Plt & $18.4 \times 10^{4} / \mu \mathrm{L}$ & $\mathrm{Cr}$ & $1.4 \mathrm{mg} / \mathrm{dL}$ \\
APTT & $36.9 \mathrm{~d}$ 秒 & $\mathrm{Na}$ & $140 \mathrm{mEq} / \mathrm{L}$ \\
PT INR & 1.55 & $\mathrm{~K}$ & $4.0 \mathrm{mEq} / \mathrm{L}$ \\
D-dimer & $6.2 \mu \mathrm{g} / \mathrm{mL}$ & $\mathrm{Cl}$ & $105 \mathrm{mEq} / \mathrm{L}$ \\
AST & $20 \mathrm{U} / \mathrm{L}$ & $\mathrm{CRP}$ & $31.1 \mathrm{mg} / \mathrm{dL}$ \\
ALT & $12 \mathrm{U} / \mathrm{L}$ & $\mathrm{CEA}$ & $5.6 \mathrm{ng} / \mathrm{mL}$ \\
LDH & $210 \mathrm{U} / \mathrm{L}$ & $\mathrm{CA} 19-9$ & $1,081 \mathrm{U} / \mathrm{mL}$ \\
T-Bile & $1.0 \mathrm{mg} / \mathrm{dL}$ & $\mathrm{CA} 125$ & $108 \mathrm{U} / \mathrm{mL}$ \\
\hline
\end{tabular}

吸となり両側肺野に著明な喘鳴を認め、10 L/ minの酸素投与下でも $\mathrm{SpO}_{2}$ は $90 \%$ を維持できなか った。心臓超音波検査では心不全の徴候はなく、 胸水と卵巣腫瘍による横隔膜圧迫が原因の急性呼 吸不全と判断し、緊急手術の方針とした。麻酔科 医師と協議の上、長時間の手術は困難であるため、 ADL低下を予防する目的で腹腔鏡下手術を選択 した。しかし、腹腔鏡下で観察し、癒着等で長時 間を要する場合や、気腹に伴い呼吸管理に難渋す る場合は開腹術へ移行することとした。術前に施 行した血液検査でPT INRが3.11と上昇していた ためワルファリン阻害目的にビタミン K $10 \mathrm{mg}$ 静注した。

手術所見：全身麻酔下に、オプティカル法で臍底 部より $5 \mathrm{~mm}$ のトロッカーを挿入し、気腹後に腹 腔内を観察した。気腹圧は $10 \mathrm{mmHg}$ で行った。 腫瘤は左卵巣腫瘍で、子宮および右付属器に異常 はなかった。腹腔内に癒着、腹膜播種の所見はな く、腹腔鏡下に体外法で摘出可能と判断した。下 腹部に $4 \mathrm{~cm}$ の小切開を加え、パスセーバー ${ }^{\circledR} を$ 着し、同部位から $5 \mathrm{~mm}$ のトロッカーを挿入した。 S.A.N.D.バルーンカテーテル ${ }^{\circledR} を$ 用いて約 4,000 $\mathrm{mL}$ の茶褐色の左卵巣腫瘍内容液を吸引した。腫
瘍の表面は平滑で肉眼所見では明らかな悪性所見 を認めず、腹腔鏡下左付属器摘出術を施行した。 手術時間は87分で、出血量は少量であった。術中 に血圧低下のためノルアドレナリン持続静注を行 ったが、人工呼吸器管理下では $\mathrm{SpO}_{2}$ は $95 \%$ 以上を 維持することができた。

術後経過：術後は手術室で抜管したが、呼吸状態 が不安定であったためICUに入室した。術直後の 胸部単純X線像を図 5 A に示す。左付属器摘出に より肺の拡張が期待されたが、肺は拡張不良であ った。慢性的な右横隔膜挙上と右胸水が原因と考 えられたため、非侵襲的補助換気を行った。しか し、吸気酸素濃度が70\%でも $\mathrm{SpO}_{2}$ が90\%を維持で きなかったため、右胸腔ドレーンを留置し、胸水 を排出した。その後の経過は良好で、術後1日目 に補助換気を離脱し、術後 2 日目に右胸腔ドレー ンを抜去し、術後 3 日目にICUを退室した。術後 6 日目にはWBCは $4,400 / \mu \mathrm{L} て ゙ \mathrm{CRP} 2.6 \mathrm{mg} / \mathrm{dL}$ と炎症反応の改善を認めた。また術後 6 日目の胸 部単純X線では肺の拡張は良好であった（図 5 B）。術後 2 日目からADLの拡大を目的としたリ ハビリを行い、術後 8 日目に独歩で退院となった。 術後合併症は認めなかった。腹水および卵巣腫瘍 内容液の細胞診は陰性であった。病理組織診では、 腫瘍の大部分は 1 層の円柱型上皮細胞で覆われて いたが、炎症細胞の浸潤を伴い肉芽増殖を示す部 分や、核の腫大や配列の不整を伴い核細胞質比の 高い上皮細胞が乳頭状に増殖する部分を認めた (図 6 )。病理組織診断は mucinous borderline tumorであった。病理組織結果と追加治療として 再開腹によるstaging laparotomyが卵巣がん治療 ガイドライン2010年版で推奨されていることを患

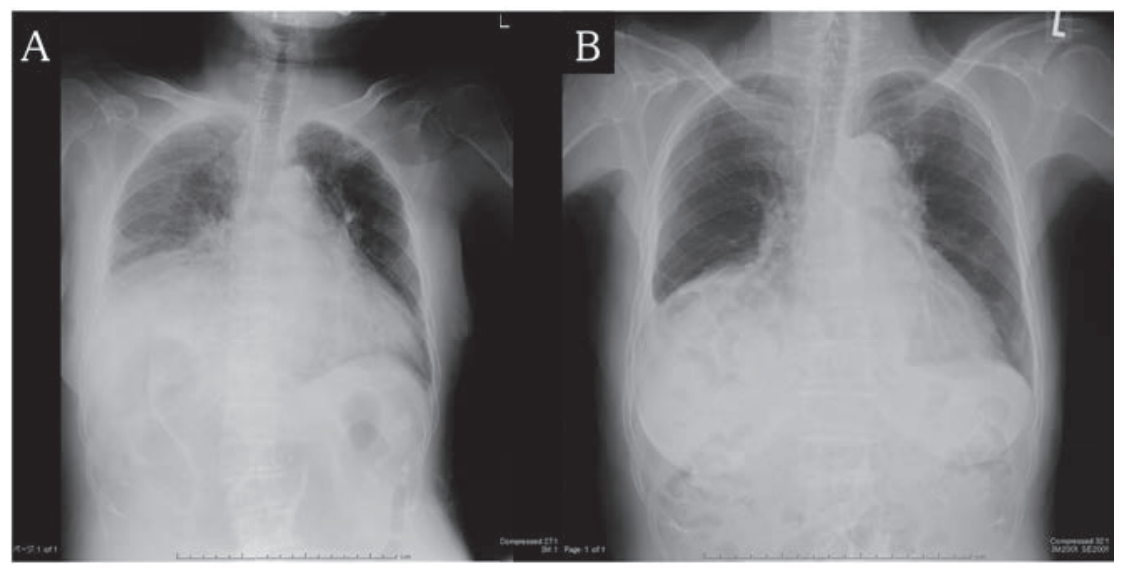

A : 術直後

B：術後 6 日目

図 5 胸部単純X線像

$A$ : 卵巣腫瘍摘出後も肺の拡張は不良であった

B : 補助換気を行い、肺は拡張した 

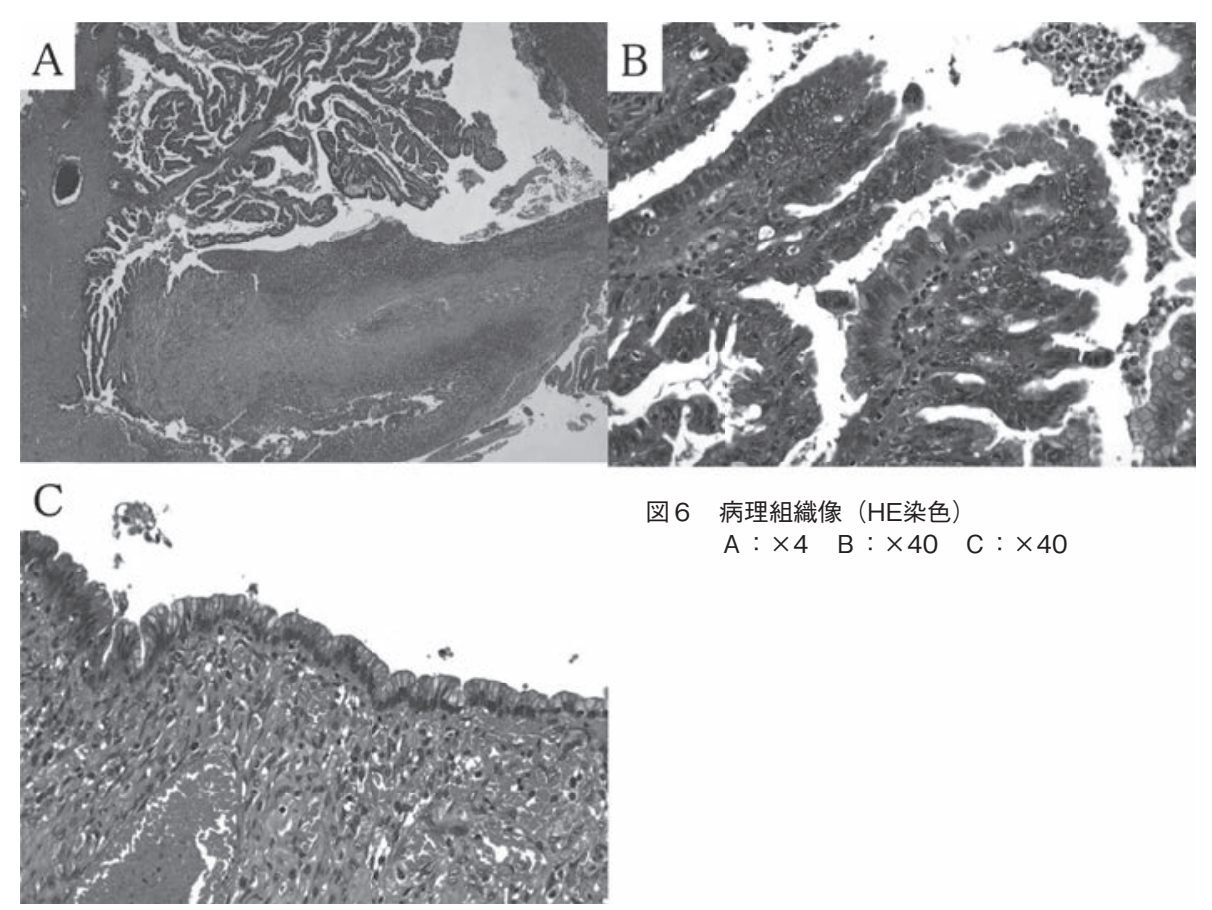

図6 病理組織像 (HE染色)

A : $\times 4 \quad$ B : $\times 40 \quad$ C : $\times 40$

者とその家族に説明した。しかし、staging laparotomyに伴う周術期合併症のリスクもあり、 追加治療は希望されず経過観察の方針となった。 術後 2 年 3 力月経過する現在、再発徴候はなく、 ADLも低下せず、外来経過観察中である。

\section{【症 例 2】}

年齢：89歳

身長 : $139.8 \mathrm{~cm}$ 、体重 : $51.1 \mathrm{~kg}$

妊娠分婏歴：3経妊3経産

既往歴: 虫垂切除術 (69歳)、白内障手術 (70歳)、 高血圧、脂質異常症、認知症

内服薬：ベニジピン $8 \mathrm{mg}$ 、カンデサルタン 8

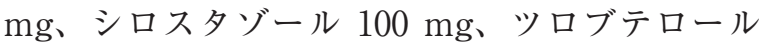
$2 \mathrm{mg}$ 、ロスバスタチン $2.5 \mathrm{mg}$ 、ウルソデオキシ

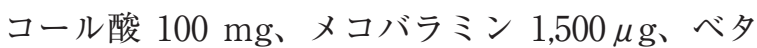
ヒスチン $6 \mathrm{mg}$

家族歴：特記すべき事項なし

現病歴：週 2 回デイサービスを利用し、着替えに 軽度の介助を要するのみで、その他のADLは自 立していた。突然の下腹部痛を主訴に当院救急外 来を受診した。

来院時現症 : 来院時、疼痛のため苦悶様表情で、 体温は $35.0^{\circ} \mathrm{C}$ 、血圧 $191 / 128 \mathrm{mmHg}$ 、脈拍は 98 bpm、 $\mathrm{SpO}_{2}$ はroom airで95\%であった。下腹部に 圧痛と腹膜刺激徵候を認めた。

検查所見：経腹超音波断層法では子宮の頭側に $7.1 \times 4.3 \mathrm{~cm}$ の壁の虚脱した囊胞性腫瘍と腹水を
認めた（図 7 )。腹部単純CTでは腹腔内腫瘍は虚 脱し、骨盤腔から肝表面に達する腹水を認め、腫 瘍内容液と腹水は同等のdensityであった（図 8 )。 血液検查所見を表 2 に示す。 $\mathrm{WBC} は 4,000 / \mu \mathrm{L}$ 、 CRPは0.1 mg/dLと炎症反応にそしく、APTTは 23.7秒、PT INRは1.00と凝固異常は認めなかった。 腫瘍マーカーはCA125が68 U/mL、CA19-9が347 $\mathrm{U} / \mathrm{mL} 、 \mathrm{CEA}$ が $6.9 \mathrm{ng} / \mathrm{mL}$ 高值を示していた。

入院後経過 : ペンタゾシンで疼痛コントロールが できず、卵巣腫瘍破裂の診断で緊急手術の方針と した。開腹手術を考慮したが、ADL低下の可能 性および抗血小板薬であるシロスタゾールの内服 による術中出血の可能性が危惧された。また開腹 術の既往があるため、腹腔内癒着の可能性を考慮 し、麻酔科医師と協議の上、低侵襲手術の選択お

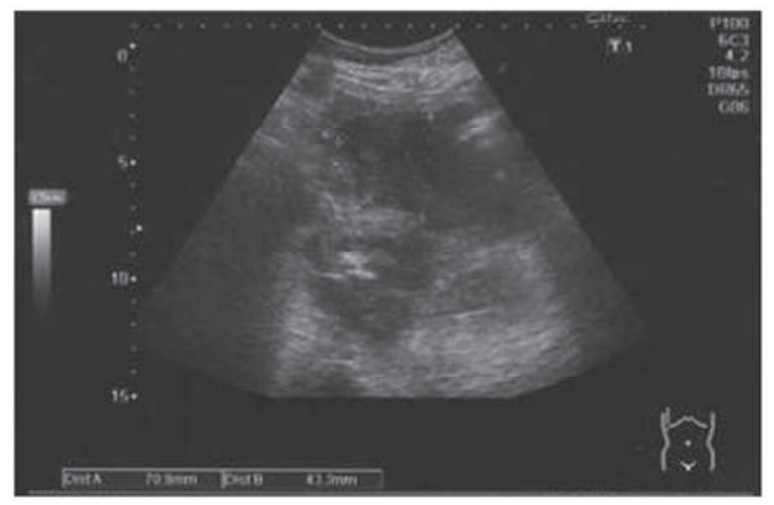

図 7 経腹超音波断層法

$7.1 \times 4.3 \mathrm{~cm}$ 壁の虚脱した囊胞性腫瘍と腹水を認める 


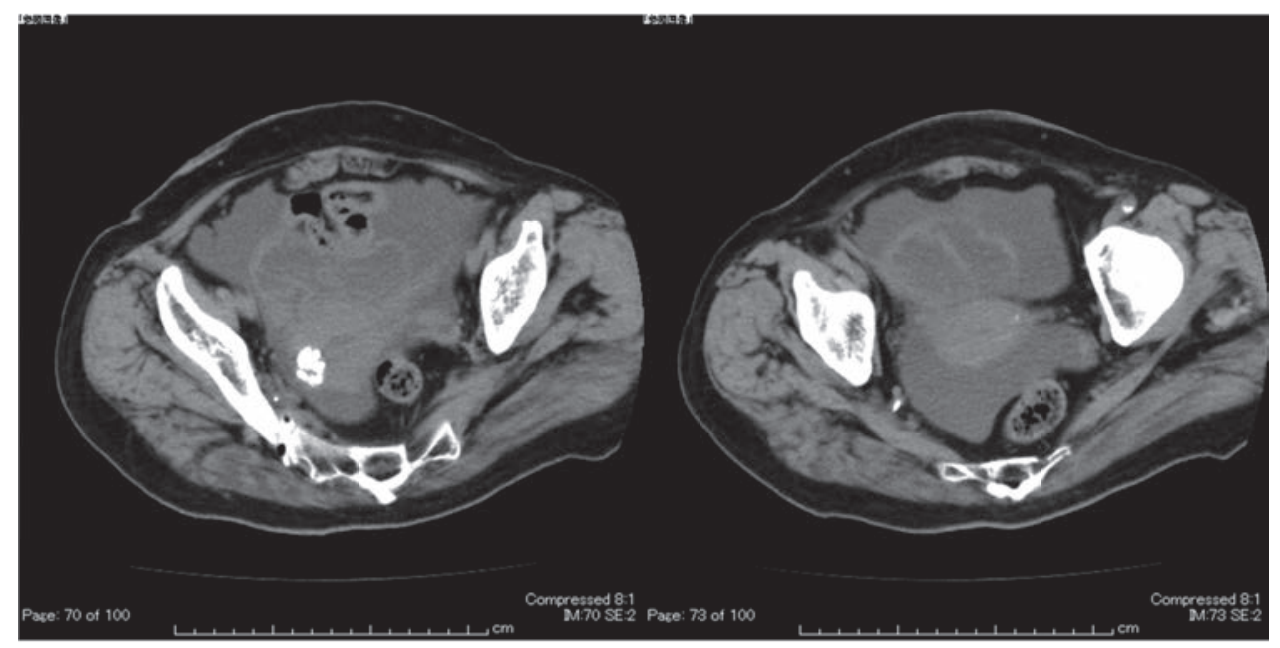

図 8 腹部単純 CT

腫瘍は虚脱し、腫瘍内容液と腹水のdensityは同等であった

表 2 血液検査所見（症例 2 )

\begin{tabular}{lclr}
\hline WBC & $4,000 / \mu \mathrm{L}$ & $\mathrm{TP}$ & $7.8 \mathrm{~g} / \mathrm{dL}$ \\
$\mathrm{RBC}$ & $491 \times 10^{4} / \mu \mathrm{L}$ & $\mathrm{Alb}$ & $4.1 \mathrm{~g} / \mathrm{dL}$ \\
$\mathrm{Hb}$ & $14.3 \mathrm{~g} / \mathrm{dL}$ & $\mathrm{BUN}$ & $14 \mathrm{mg} / \mathrm{dL}$ \\
Plt & $21.4 \times 10^{4} / \mu \mathrm{L}$ & $\mathrm{Cr}$ & $0.9 \mathrm{mg} / \mathrm{dL}$ \\
APTT & $23.7 \mathrm{\text { 秒 }}$ & $\mathrm{Na}$ & $143 \mathrm{mEq} / \mathrm{L}$ \\
PT INR & 1.00 & $\mathrm{~K}$ & $4.0 \mathrm{mEq} / \mathrm{L}$ \\
D-dimer & $2.0 \mu \mathrm{g} / \mathrm{mL}$ & $\mathrm{Cl}$ & $107 \mathrm{mEq} / \mathrm{L}$ \\
AST & $15 \mathrm{U} / \mathrm{L}$ & $\mathrm{CRP}$ & $0.1 \mathrm{mg} / \mathrm{dL}$ \\
ALT & $8 \mathrm{U} / \mathrm{L}$ & $\mathrm{CEA}$ & $6.9 \mathrm{ng} / \mathrm{mL}$ \\
LDH & $211 \mathrm{U} / \mathrm{L}$ & $\mathrm{CA} 19-9$ & $347 \mathrm{U} / \mathrm{mL}$ \\
T-Bile & $0.6 \mathrm{mg} / \mathrm{dL}$ & CA125 & $68 \mathrm{U} / \mathrm{mL}$ \\
\hline
\end{tabular}

よび腹腔内の癒着状況を把握する目的で腹腔鏡下 手術を施行した。

手術所見：全身麻酔下に、オプティカル法で臍底 部より $5 \mathrm{~mm}$ のトロッカーを挿入し、気腹後に前 腹壁に癒着のないことを確認した。下腹部に 4

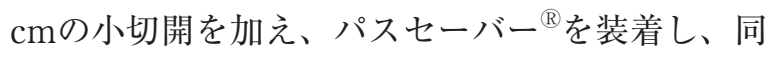
部位から $5 \mathrm{~mm}$ のトロッカーを挿入した。鏡視下 では腫瘤は右卵巣腫瘍で、15 $\mathrm{mm}$ の穿孔部を認 め、虚脱していた。約 $400 \mathrm{~mL}$ の茶褐色腹水と卵 巣腫瘍内容液を吸引した。腫瘍の表面は平滑で肉 眼所見では明らかな悪性所見を認めず、腹腔鏡下 右付属器摘出術を施行した。子宮および左付属器 に異常はなかった。手術時間は77分で、出血量は 少量であった。

術後経過 : 術直後より血圧が192/117 mmHg と再 上昇したため、ICUに入室し、ニカルジピン点滴 による降圧治療を開始した。術後経過は良好で、 術後 1 日目より降圧剤の内服を再開し、術後 2 日 目には血圧は115/59 mmHgと低下し、ICUを退
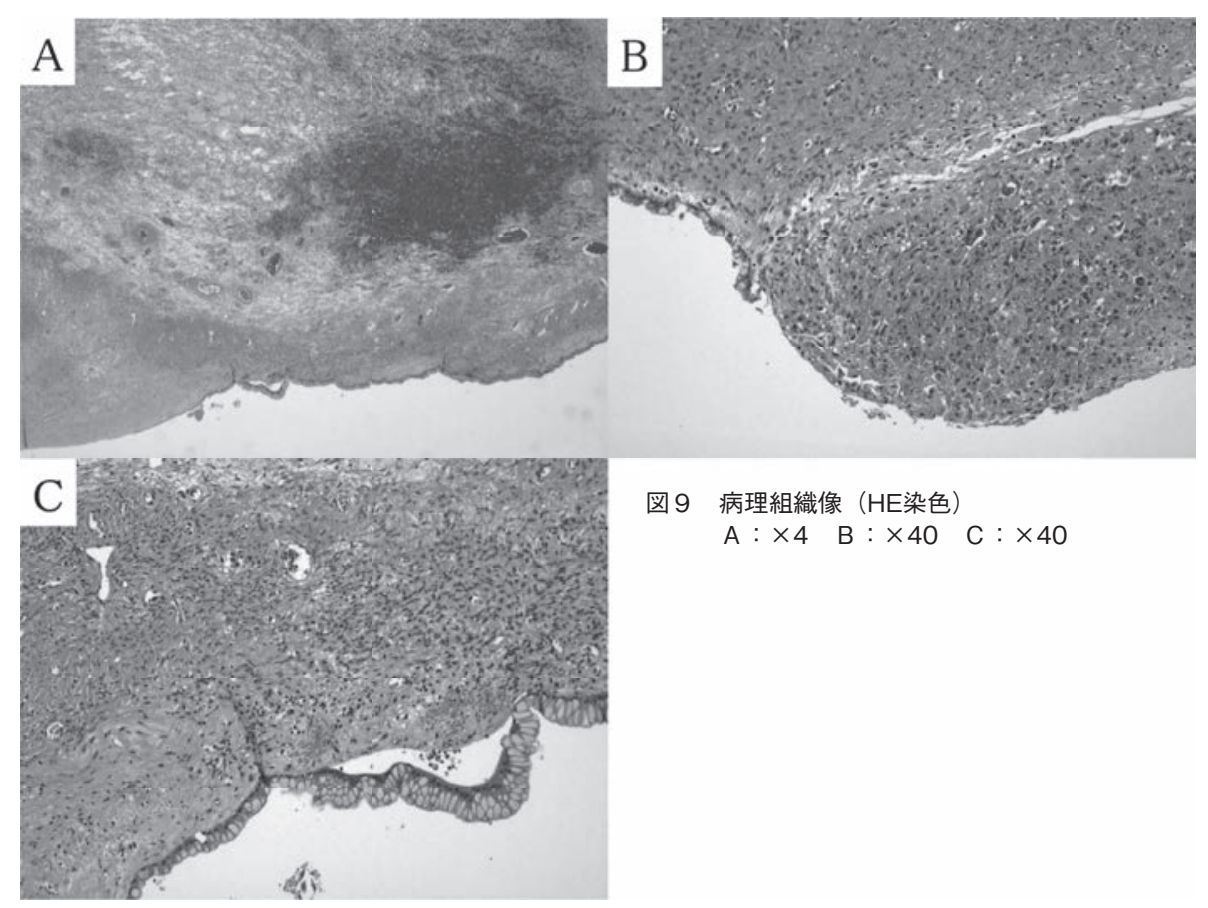

図9 病理組織像 (HE染色) A : $\times 4$ B : $\times 40 \quad$ C : $\times 40$ 
室した。また同日よりADLの拡大を目的とした リハビリを行い、術後 9 日目に独歩で退院となっ た。術後合併症は認めなかった。病理組織診では、 腫瘍内腔は粘液を多く含有する 1 層の円柱型細胞 で覆われていた。核は基底側に配列しており、核 細胞質比は低く、mucinous cystadenomaの診断 であった（図 9 )。術後 1 年経過する現在、ADL の低下もなく、日常生活を送っている。

\section{【考察】}

本邦において腹腔鏡は1992年に胆囊摘出術が保 険適応されたのち、1994年に婦人科領域で腹腔鏡 下手術が保険適応となった ${ }^{2)}$ 。その後、腹腔鏡下 手術の急速な進歩に伴い適応は拡大し、良性卵巣 腫瘍では卵巣腫瘍摘出術の $66.7 \%$ が、付属器摘出 術の $25.5 \%$ が腹腔鏡下手術でなされている3)。産 婦人科内視鏡手術ガイドライン 2013 年版では、良 性卵巣腫瘍に㧈いて「手術適応がある場合、高齢 者に対しても腹腔鏡手術は推奨される」としてい る ${ }^{4)}$ 。近年、わが国は高齢社会から超高齢社会に なりつつあるが5)、超高齢者に対する腹腔鏡下手 術の報告はきわめて少ない1)。

本邦では高齢者の増加に伴い、基礎疾患を有す る患者を手術する機会が増えてきた ${ }^{5)}$ 。80歳以上 の症例では43.4-73.5\%が術前に何らかの基礎疾患 を有 ${ }^{6.7)}$ 、高血圧、心疾患、脳血管障害、呼吸器 疾患が多い6.8) 。基礎疾患を有する患者では術後合 併症発症率と直接手術死亡率が高く7)、術前の performance statusが高くなるほど直接手術死亡 率も上昇する ${ }^{6}$ 。特に、急性腹症を発症した場合 には、70歳以上の高齢者では癌死を除き死亡率は 19\%に上り、90歳代になると死亡率は $33.3 \%$ と更に 高くなり、高齢であるほど予後が悪いとされる 鳥越らによると80歳以上の急性腹症に対する緊急 手術に㧈いては、術前に全身疾患を合併した患者 の直接手術死亡率は $35.5 \%$ 高率であった ${ }^{6)}$ 。高齢 者では一旦homeostasisが破綻すると回復に難啮 するので、手術に際しては術前に全身状態を十分 検索する必要がある7)。しかし、高齢者の急性腹 症は予後不良のため ${ }^{5)}$ 、緊急手術が必要な場合は、 基礎疾患に対する十分な把握や対策もできないま ま手術に踏み切る場合もあり、現在でもなお おhigh riskな手術を余儀なくされている ${ }^{5-7)}$ 。80歳以上の 症例では、術後合併症は45.1-46.5\%で生じたとの

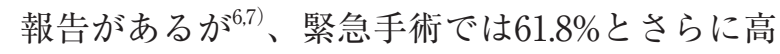
率となる ${ }^{6)}$ 。特に呼吸器合併症として、術後咳嗽 反射や喀痰排出が困難となり、無気肺や肺炎を併
発する可能性が高くなることから ${ }^{9)}$ 、早期の離床 が望ましい。また、超高齢者では手術の侵襲によ りADLの低下をきたすため、より低侵襲な手術 が望まれる。

腹腔鏡下手術は低侵襲で、術後早期の離床、リ ハビリが可能であり、超高齢者のADLの維持に は理想的である。しかし腹腔鏡下手術では、従来 法である開腹手術や腟式手術では起こりえない合 併症も生じうる ${ }^{1)}$ 。腹腔鏡下手術で起こりうる合 併症の発症率は0.1-10\%とされ、その半数以上が 腹腔内に達する際に生じ、20-25\%は術後に発症 するとされる ${ }^{10)}$ 。具体的にはトロッカー穿刺時の 皮下血腫、大血管損傷や小腸などの腹腔内臓器損 傷、超音波メスなどの術中に使用する機器の作用 原理の認識不足からの血管損傷、腸管損傷や器具 先端の破損、気腹法によるガス塞栓、皮下気腫、 呼吸器合併症や循環器合併症、トロッカー抜去時 の出血やトロッカー孔からのヘルニアなどの合併 症が報告されている ${ }^{1,11,12)}$ 。特に超高齢者において は、気腹による術中、術後の呼吸や循環に関する

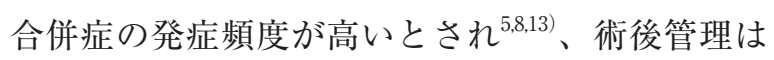
集学的治療を要する場合も多く、より慎重に行う べきと考えられる。

婦人科領域の超高齢者に対する本邦での腹腔鏡 下手術の報告を表 3 に示す。検索し得た限りでは、 2000 年以降に 11 例の報告例があった ${ }^{13-17)}$ 。年齢は 85-99歳で、主訴は腹部膨満感が 3 例、腹痛、下 腹部痛が 5 例であった。全例が術前に卵巣腫瘍と 診断されていたが、1例は術中に傍卵巣囊胞と診 断された。2 例は卵巣境界悪性腫瘍であった。手 術時間は30-96分で、術後入院日数は3-6日であっ た。ほとんどの症例で基礎疾患、内服薬、術中の 合併症、ICU入室の有無についての記載はなく、 重篤な基礎疾患を有する症例はなかったが、1例 に術後合併症を認めた。その症例は抗凝固療法が なされていないにもかかわらず、術後 3 日目に臍 下から聎骨に抢よぶ広範囲に皮下出血をきたした 症例であった ${ }^{14)}$ 。自験例の手術時間は77分と87分 であり、過去の報告と比較しても大差なく手術を 完遂できていた。術後の入院日数は 8 日と 9 日で あったが、 2 例ともに退院可能と判断した後に、 患者家族の都合で入院が 2 日間延長されていた。 入院日数のみを考慮すると、既知の報告と同様で あったが、2 例とも高血圧や脂質異常症、慢性心 不全などの基礎疾患を有し、抗凝固療法が施行さ れていた。そのため、術中、術後の呼吸循環動態 が不安定であり ICU管理を必要としたが、幸いに 
表 3 婦人科領域の超高齢者に対する本邦での腹腔鏡下手術の報告

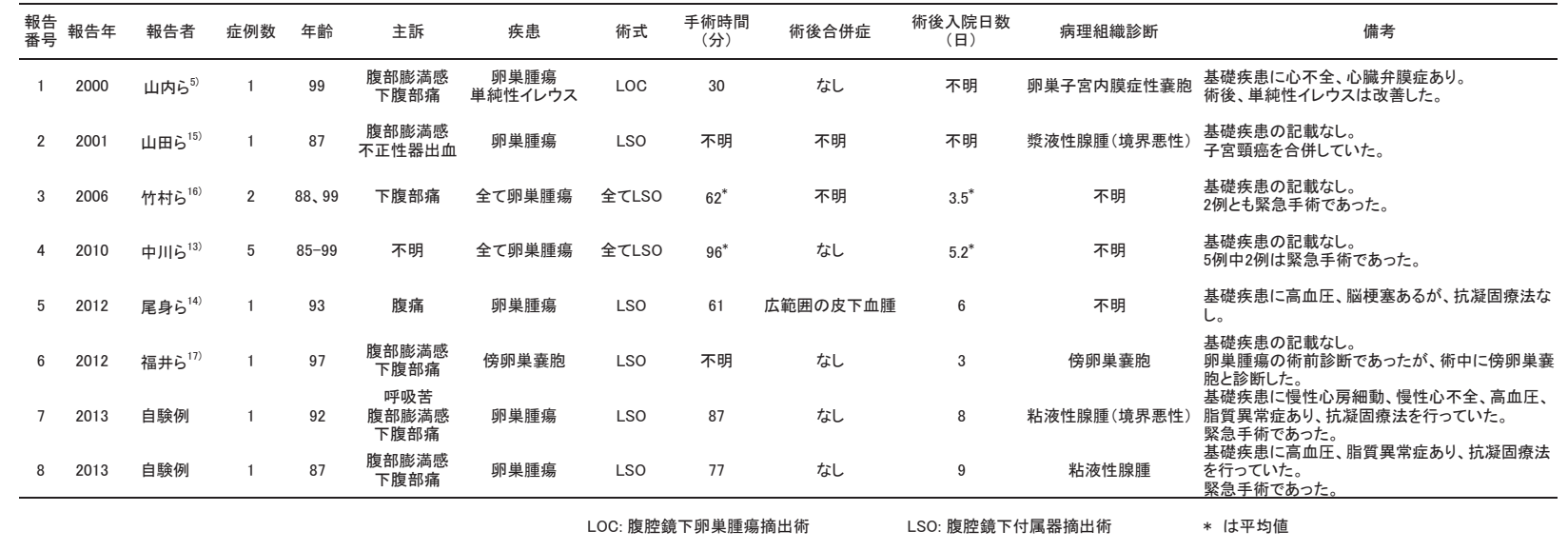

も術後合併症は発症しなかった。また、術後早期 にリハビリを行うことでADLを維持した状態で 退院することができた。

\section{【結 論】}

超高齢者では基礎疾患を有することが多く、基 礎疾患の治療薬に対する副作用への適切な対応お よび術中、術後合併症に対する集学的管理が必要 である。これらの質保証がなされていれば、腹腔 鏡下手術は術後早期の離床、リハビリが可能であ り、ADLを維持できる点で超高齢者に対しても 有用であり、今後超高齢者の手術療法として定着 していくものと期待される。

\section{【文献】}

1）伊熊健一郎、松本 貴: 腹胿鏡下手術 合併症対策、 日産婦会誌、2008；40：1121-1132.

2 ）國方建児、他：婦人腹腔鏡下手術、日産婦香川会誌、 $2002 ; 4: 5-12$.

3）塩田 充、他：開腹手術、腹腔鏡下手術の割合に関 する調查、産婦手術、2005；16：114-118.

4) 日本産婦人科内視鏡学会：第2章 良性卵巣腫瘍、産 婦人科科内視鏡手術ガイドライン2013年版、2013； 25-31、金原出版.

$5 ）$ 山内希美、田辺 博、可知宏隆：99歳の超高齢者の 急性腹症に対し腹脉鏡下手術が有効であった1例、外 科、 $2000 ; 62: 245-248$.

6 ）鳥越敏明、他：80歳以上高齢者腹部手術例の検討-と くに緊急例の死亡例について、外科、1990；52： 501-505.

7 ）真弓俊彦、他：80歳以上の高齢者急性腹症228例の臨 床的検討、腹部救急診療の進歩、1988；8：159-164.

8 ）古本雅彦、原田英樹：高齢者急性腹症－全国労災病 院外科集計一、腹部救急診療の進歩、1989；9：519524.

9）元木良一、井上 仁：急性腹症の外科的処置に際し
て注意すべき基礎疾患、外科治療、1996；74：341348.

10) Magrina JF : Complications of laparoscopic surgery. Clin Obstet Gynecol $2002 ; 45$ : 469-480.

11）日本内視鏡外科学会：内視鏡外科手術に関するアン ケート調査－第9回集計結果報告【7】産婦人科領域 - 、 日内視鏡外会誌、2008；13:569-581.

12）日本産婦人科内視鏡学会：産婦人科内視鏡手術に関 するアンケート調査 - 2006年度と 2007 年度の集計結 果報告一、日産婦内視鏡会誌、2008；24：515-520.

13）中川 慧、他：85歳以上の超高齢者における腹腔鏡 手術の安全性に関する後方視的検討、日産婦内視鏡 会誌、 $2010 ； 26: 152$.

14）尾身牧子、他：93歳の症例に腹腔鏡下手術を施行し、 腹壁の広範囲に皮下出血を来した1例、日産婦内視鏡 会誌、 $2012 ; 28: 256$.

15）山田隆司、岡本由記子、笠松 源：高齢者卵巣large cystic tumorに対する腹腔鏡併用手術、日産婦内視鏡 会誌、 $2001 ; 17: 100$.

16）竹村昌彦、他: 超高齢者に対する腹腔鏡手術の2症例、 日産婦内視鏡会誌、2006；22：100.

17）福井章正、河野亮介、川越秀洋：97歳の超高齢者に 対して行った腹腔鏡下付属器摘出術の 1 例、日産婦内 視鏡会誌、 $2012 ; 28: 318$. 